\title{
ESPAÇAMENTOS NA EDUCAÇÃo
}

Wenceslao Machado de Oliveira Jr

O quarto número da revista ETD - Educação Temática Digital publica o dossiê Educação, visualidades e espacialidades no contemporâneo, organizado pelas professoras Valéria Cazetta e Ana Maria Hoepers Preve e pela doutoranda Cláudia Rodriguez Ponga Linares.

Os nove artigos presentes no dossiê trazem aos leitores espacialidades e visualidades insurgentes. Insurgentes justamente porque emergem na superfície do que tem sido a educação, buscando mover o território educativo em outras direções e sentidos ou mesmo levar esse território a mover-se através de sem sentidos que não apontam direções mas sim fazem todo o conjunto do território desterritorializar-se. As experimentações e conceitos mobilizados em cada artigo fazem o território educativo oscilar ao ser atravessado por uma dança de projecionistas, um enxame de mapas loucos, um fanzine que se oficina, um bando de alunos com celulares ligados filmando tudo ao seu redor, fazendo da educação e da escola territórios heterotópicos, em metamorfose frequente, habitados por corpos nômades, ambulantes, indignos que, justo por isso, afirmam o direito a olhar.

O espaço e as espacialidades aparecem aqui como questões atinentes e pertinentes para pensar a educação contemporânea, notadamente aquela onde as imagens constituem e modulam aprendizagens e subjetivações, (in)visibilizando outras potências e novos agentes educativos e educadores.

Ao adentrarmos os textos e imagens do dossiê encontramos variadas escalas onde espacialidade e política se engendram na configuração de territórios intensivos e extensivos... corpos e guetos e(m) estratégias de controle, pensamento e poesia. Ao longo dos artigos somos levados a reparar na rede como referência para pensar o planeta, na existência de processos educativos implicados e necessários às estratégias de uso de imagens para se 
realizar a guerra e a dança dos (e entre os) corpos, bem como nas resistências micropolíticas ativadas por grupos diversos e dispersos no espaço da escola, da cidade e do planeta.

Agradecemos às organizadoras e desejamos aos leitores excelentes encontros no e com o espaço feito (de) palavras e imagens.

WENCESLAO MACHADO DE OLIVEIRA JR

Doutor em Educação pela Universidade Estadual de Campinas, UNICAMP, Campinas, SP - Brasil

Professor Livre-Docente do Departamento de Educação, Conhecimento, Linguagem e Arte da Universidade Estadual de Campinas, UNICAMP, Campinas, SP - Brasil.

E-mail: wenceslao.oliveira@gmail.com

Como citar este documento:

MACHADO OLIVEIRA JR., Wenceslao. Espaçamentos na educação. ETD - Educação Temática Digital, Campinas, SP, v. 18, n. 4, p. 736-737, nov. 2016. ISSN 1676-2592. Disponível em:

<http://periodicos.sbu.unicamp.br/ojs/index.php/etd/article/view/8647492>. Acesso em: 16 nov. 2016. doi:http://dx.doi.org/10.20396/etd.v18i4.8647492. 